Brigitta Hennen-Benzing (Mainz University) offered a paper on the problem of minorities with reference to a social theory of inequality, rejecting Dahrendorf's views on the origin of social inequality.

Several working groups discussed in detail the problems raised by the case studies offered to the meeting. Apart from Möhlig's paper, already mentioned, the participants discussed a paper by Gerhard Grohs (Free University, Berlin) who had studied the role which Europeans play as guest workers in East Africa. The diverging tendencies of assimilation and self-identification in the former kingdoms of Buganda and Toro were discussed by Jürgen Jensen (Hamburg University). Elhanan Hagolani (Hamburg) delivered a paper on the problems of integrating ethnic minorities in the Ivory Coast and showed how the independent Ivory Coast had inherited its policy of national integration from the French colonization, insisting on the national use of the French language, prohibiting the wearing of national dress by civil servants to erase ethnic distinctions, and attempting to abolish economic inequalities between the various regions of the country by distributing development projects among them. Ebow Mensah, a Ghanaian sociologist working in Germany, contributed a topical paper, dealing with the deportation of African foreigners from Ghana. He, too, showed that their economic situation determined their position as minorities in Ghana.

This third annual meeting of Africanists in Germany has provided a further example of how useful interdisciplinary research work can be, although it cannot be denied that it is often very difficult to find a common theoretical basis from which to start.

\title{
Bi-Centenary of the Birth of Mungo Park
}

ThIs was celebrated at the University of Edinburgh on I I September I97 I by an open forum, which included addresses by Professor Christopher Fyfe on Mungo Park in the Perspective of African Exploration, and by Mr. Tony Kirk-Greene on The Land of Mungo Park. It was followed by an excursion to Selkirk to visit the special exhibition of relics of Mungo Park's explorations.

\section{Conference of Directors of Economic and Social Research Institutes in Africa}

THE first Conference of Directors of Economic and Social Research Institutes in Africa was held in October 1964 and the second in February 1967. At its third Conference, held in Nairobi in February $197 \mathrm{I}$, it was decided to create a permanent Secretariat for CODESRIA, charged with archival, research recording, co-ordinating and dissemination functions. For this purpose the United Nations African Institute for Economic Development and Planning (IDEP) was designated as the official CODESRIA Depository Centre and a Standing Committee elected (Chairman: Dr. H. M. A. Onitiri, NISER, Ibadan) and charged with the task of furthering the objectives of CODESRIA on a continuing basis.

CODESRIA's main objective is to group all research institutions, centres, and University departments in Africa into a permanent organization with a view to effective co-ordination of social science research in the fields of economics, sociology and anthropology, political science, and psychology. At present eighty-six research centres in thirty-eight African countries are actively involved in CODESRIA's activities.

The Centre is now ready to supply data on research projects, completed, under way, or planned since 1967. A bilingual (English/French) African Development Research Annual is to be published every year from 1972 and a bilingual Quarterly Journal of African Development is also planned to incorporate fundamental research results originating from participating institutes and centres.

Further information may be obtained from Mr. George C. Abangwu, Co-ordinator, CODESRIA Depository Centre, IDEP., B.P. 3186 , Dakar. 